\title{
Turkish Public Opinion on the Coup Allegations: \\ Implications for Democratization
}

\author{
Yaprak Gürsoy
}

\begin{abstract}
What is the impact of the recent allegations of coup plots in Turkey for democratization? At first glance, the Ergenekon case seems to be furthering democratization by cleansing the military of coup plotters, strengthening the hands of the civilians in reforming civil-military relations and reshaping the public's attitudes toward the military. However, this paper analyzes Turkish public opinion on the trials, based on an original nationwide opinion survey designed to understand attitudes towards the military. Contrary to the superficial reading of the consequences of the coup trials, the survey findings demonstrate that Turkish politics is highly polarized on the court case. This type of polarization is indicative of an unconsolidated democracy where actors mutually suspect each other's intentions. Thus, instead of contributing to democratic consolidation, the Ergenekon case cuts deeply into the already existing divides in society and, as a result, jeopardizes further democratization.
\end{abstract}




\title{
POLITICAL SCIENCE QUARTERLY
}

\section{Turkish Public Opinion on the Coup Allegations: Implications for Democratization}

\author{
YAPRAK GÜRSOY
}

Civil-military relations in Turkey took an exceptional turn in 2007 with the start of an investigation, known to the public as Ergenekon, that implicated military officers in coup plots. The inquisition can be traced back to March 2007, when the alleged diaries of a former commander of the navy published by a weekly magazine exposed plans of a military intervention against the Justice and Development Party (Adalet ve Kalkınma Partisi, AKP) government in 2003-2004. In the subsequent years, other plots were revealed.Among them the Sledgehammer investigation started as a separate inquisition in January 2010, and 325 suspects, including the former first army commander and former commanders of the air force and navy, were found guilty and received prison sentences in September 2012. In June 2014, the Constitutional Court overturned this decision and all of the accused were released from prison. Although arguably the Sledgehammer plot and other court cases also had a significant impact on public views regarding the Turkish armed forces, this article focuses only on the consequences of the Ergenekon case between 2007 and 2012 .

With the start of the official Ergenekon investigation in June 2007, hundreds of people, including journalists, academics, and retired and active-duty military officers of various ranks, were accused of coup plans and put on trial. In August 2013, the court reached a verdict and among the 275 individuals who had been formally charged, 31 were sentenced for attempting to stage a coup, 11 were found guilty of leading the Ergenekon terrorist organization, and 194 were 
condemned to imprisonment for being members of the same organization or aiding it. ${ }^{1}$ The accused individuals were said to have established Ergenekon with the purpose of generating chaos in society that would build up opposition to the ruling AKP. The allegations included attacks against minority groups, bombing mosques, assassinating public figures, blowing up a newspaper, and setting up Web sites in order to trigger disorder and discontent in Turkish society that would provide the justification for the military to stage a coup and intervene against the government. In March 2014, the Constitutional Court ruled that the rights of a number of Ergenekon suspects were violated and released all suspects from prison. Indeed, the Ergenekon trial is not yet over, as an appeals procedure is still in progress. There is a good chance that eventually all suspects will be acquitted. Nevertheless, the investigation and the trials were unprecedented in Turkish history because, for the first time, high-ranking officers, including a former chief of the General Staff and commanders of the armed forces, were sentenced to life imprisonment for allegedly plotting coups to topple an elected civilian government.

What was the effect of this unparalleled court case on Turkish democratic consolidation between 2007 and 2012? At first glance, it seems that the Ergenekon case furthered the ongoing democratization process by cleansing the military of coup plotters, strengthening the hands of the civilians in reforming civil-military relations, and reshaping the public's attitudes toward the military. In a country that has witnessed two military coups d'état $(1960,1980)$ and two military interventions that forced the governments of the day out of power $(1971,1997)$, these developments are undeniably significant.

Yet this article argues that despite these favorable changes in politics, the Ergenekon case did not have a positive effect on Turkish democratic consolidation. In order to assess the impact of the coup investigation on Turkish politics, the article uses the data set of the Survey on the 
Armed Forces and Society in Turkey (SAFST), conducted in October 2011 by face-to-face interviews with 2,775 people. $^{2}$ The results of the survey indicate that Ergenekon contributed to polarization among political groups. Centrifugal tendencies in politics are not conducive to consolidation, especially when they are over issues such as coup plots that have direct implications for the survival of the regime.

The first section of the article briefly analyzes the seemingly positive consequences of the Ergenekon trials for Turkish democracy. The second part looks into the impact of polarization on democratic consolidation theoretically and discusses the recent increase in the divergence of views in Turkish politics as a result of the Ergenekon case. The third part of the article tests the hypotheses derived from the theoretical discussion and observations of Turkish politics using the SAFST data. The conclusions from the empirical analysis indicate that, overall, the Ergenekon investigation did not aid the consolidation of democracy in Turkey.

\section{THE SEEMING CONTRIBUTIONS OF ERGENEKON TO TURKISH DEMOCRACY}

Students of Turkish politics analyzing the court cases in Turkey would conclude that the Ergenekon case had important consequences for democratization. Once the definitions of democracy and regime consolidation are considered, the significance of the coup accusations and trials for democratization are revealed. ${ }^{3}$

In order to consider a country fully democratic, the armed forces and other unelected institutions should not have powers and prerogatives that would challenge or restrict the decision-making capabilities of elected officials, such as the government and parliament. ${ }^{4}$ If the military has tutelary powers and policy domains in which it makes decisions on its own, it is not possible to refer to that country as a liberal democracy. Although related to the procedures of 
liberal democracy, the concept of consolidation is different and goes beyond the institutional and legal prerequisites. For democratic consolidation, all significant actors and, in countries where the military historically had political powers and prerogatives, the armed forces should attitudinally and behaviorally endorse democracy. If a group of actors with potentially significant power to disturb the political system does not consider democracy the best regime suitable for the country, then democracy is not consolidated. ${ }^{5}$

Given these definitions of liberal democracy and democratic consolidation, arguably, the coup trials contributed to Turkish democratization. First, to the extent that the investigation led to the arrests and trials of coup plotters in the armed forces, it is possible to claim that those officers, who had a mind-set that could disrupt the normal functioning of the regime, were cleansed from the military. Antidemocratic attitudes and beliefs among the personnel of the armed forces could be threatening to democracy, especially if those officers have the necessary resources to stage a coup d'état. Therefore, by definition, the trials of putschists were a positive development.

Second, it could be asserted that the Ergenekon trials strengthened the hands of the politicians vis-à-vis the General Staff and gave impetus to reforms in civil-military relations. The military has been a political actor since the founding of the Republic of Turkey in 1923, with increasing importance after the 1960 coup. Until the last decade, the significance of the military in political decision making had continued, and aside from direct and indirect military interventions, the armed forces exercised tutelary powers through several institutional mechanisms, including the National Security Council. ${ }^{6}$ After 1999, when the prospect of European Union (EU) membership was popular both among the public ${ }^{7}$ and within the ranks of the military, ${ }^{8}$ the politicians started to reform civil-military relations as part of the set of legal 
amendments that were required by EU conditionality. ${ }^{9}$ However, the reform process had come to a standstill by 2006, when the prospects for EU membership dwindled, in part because of the decision of the EU to freeze the negotiation process with Turkey.

The drive to civilianize the regime was stimulated after 2007 with the start of the Ergenekon trials. The likelihood of the General Staff reacting to the AKP government and resisting or controlling the reform process became almost impossible, as such interventions were now seen as exercising undemocratic powers. The acquiescence of the General Staff to the arrests of the suspected officers changed the balance of power in favor of the civilians and gave assurance to the politicians that a military intervention to protect the political privileges of the armed forces was impossible. With the Ergenekon case, the military was purged of putschist officers, and, at the same time, it became clear that any attempt at an intervention would warrant a strong judicial reaction and probable penalties for those who were suspected of being involved with coup plans. Thus, after 2007, in a political environment that gave more security to the civilians, the initiative to carry out amendments in civil-military relations was renewed.

Among some of the significant reforms, the following can be cited: the abolishment of the Protocol on Cooperation for Security and Public Order, which had justified the military in carrying out operations and gathering intelligence independent of the civilians; the involvement of the civilians in the promotion of senior-ranking officers; judicial review of the decisions of the High Military Council involving purges from the armed forces; the restriction of the legal authority of military courts; and the removal of the military troops stationed outside of the parliament. ${ }^{10}$

A third possible contribution of the investigation to democratization was the changing stance of the public toward the military and, especially, a drop in the level of confidence in the 
armed forces. Even though the results from the public opinion surveys conducted in the 1990s and early 2000s indicate high confidence in the military among all social classes and demographic groups, ${ }^{11}$ Eurobarometer surveys demonstrate that after 2007, there was a significant decrease. ${ }^{12}$ Similar to other surveys conducted in the early 2000s, the Eurobarometer surveys show that in these years, the Turkish public was generally supportive of the armed forces. The Eurobarometer surveys posed the following question to respondents: "I would like to ask you a question about how much trust you have in certain institutions. For each of the following institutions, please tell me if you tend to trust it or tend not to trust it?" ${ }^{13}$ The army was one of the institutions that the surveys asked about, and in the early 2000s, on average, 88 percent of the Turkish respondents said that they tend to trust the army, while 10 percent declared that they tend not to trust it. These results were relatively higher than the trust that respondents accorded to other institutions, such as the government, parliament, the legal system, and political parties. Moreover, compared with the attitudes in EU member states, the Turkish public trusted the armed forces more than the European publics trusted their militaries. ${ }^{14}$

Although confidence in the military was high in the early $2000 \mathrm{~s},{ }^{15}$ the results of the surveys started to change after 2007. In 2008, 83 percent of the respondents declared that they tend to trust the military, while the percentage of the people who declared that they do not have confidence in the military increased approximately five percentage points. The number of people in Turkey who asserted that they tend not to trust the military increased further to 20 percent in 2009 and to 28 percent in 2010 . Conversely, the trust people accorded to the military decreased to 77 percent in 2009 and to 69 percent in $2010 .{ }^{16}$ Once the respondents who gave a “don't know" answer are omitted from the calculations, it can be seen that that by 2010 , the Turkish public trusted its army even less than the EU societies (see Figure 1). 
Moreover, when the data from different regions of Turkey are compared, it becomes clear that the drop in the levels of trust for the military was uniform across the country. Even though there were various ups and downs in trends, by 2010, all of the regional averages had fallen below the strong trust accorded to the army in the first half of the 2000s. Most regions were above the Turkish average because respondents from southeastern Anatolia, where the majority the population is from Kurdish ethnic origin, consistently declared lower levels of trust in the military compared with the respondents from other regions. Given that the Turkish military was in combat with Kurdish forces in this region, this finding is expected. Another interesting observation when compared with the general trend is the results in Istanbul. The biggest city in Turkey, with a population of more than 10 million inhabitants from various occupational, ethnic, and religious backgrounds and ideological convictions, witnessed the most significant drop in trust levels. In 2007, 92 percent of the Istanbul respondents that they trusted the military. However, in 2008, the first dramatic fall took place, with 65 percent saying that they tend to trust the military.In 2010, only 54 percent declared a positive view. Despite this important point, Istanbul and southeastern Anatolia share the common inclination of a drop in trust levels observed in all regions of Turkey.

Although it is not possible to make a definitive claim as to which factors led to the change in the trust levels accorded to the military across regions and generally in Turkey, the timing of the drop in the Eurobarometer surveys indicates that the Ergenekon investigation might have been the crucial event. ${ }^{17}$ Changes in public opinion started to take place in the Turkish average in 2008, only a year after the start of the Ergenekon investigation in 2007. The critical breaking point seems to have occurred following the coup allegations, even though levels of trust started to diminish even further in the subsequent years. 
The question of public confidence in the armed forces is significant for Turkish democratization for two reasons. First, public attitudes toward the military have the potential to influence the decisions of the politicians and affect their willingness to curtail the tutelary powers of the military. Until the reform process that started in 1999, civilians hesitated to restrain the tutelary powers of the military, mainly because they feared that such an action would trigger a coup against them, but also because it was believed that such reforms would be unpopular. ${ }^{18}$ Similarly, once the reform process started (mainly as a result of EU conditionality), many analysts of Turkish politics feared that such amendments in civil-military relations would remain only on paper, and military tutelage would continue. ${ }^{19}$ Such skepticism was a result of the belief that the military derived its legitimacy not only from the constitution and the legal framework that allowed it to exercise political powers but also from the acceptance of such a role among the public. ${ }^{20}$ The popularity of the military was seen as an impediment, standing in the way of substantively reforming civil-military relations. Thus, in addition to strengthening the hands of the civilians by thwarting coup plotters (as outlined earlier), arguably, the Ergenekon investigation also contributed to the civilianization of the regime by turning public opinion in favor of the politicians and the reforms.

The second reason why the decreasing level of trust in the military is important for democratization is that confidence in the armed forces is a symptom of unconsolidated democracy in Turkey. Quantitative research has suggested that confidence in the military and support for democracy are positively related in the Turkish case. Two studies that have analyzed World Values Survey results in different years have demonstrated that among those who lend support to democracy, confidence in institutions of order, including the military, is higher. ${ }^{21}$ The assertion that democratic individuals in Turkey trust the military, which has staged coups and 
intervened against it, makes sense once it is considered that the armed forces justified its intrusions as attempts to protect democracy and guard it against internal threats. ${ }^{22}$ Based on their findings in a survey conducted in 2006, Çarkoğlu and Toprak conclude that "although the majority of the public does not agree with the idea that only a military regime can solve Turkey's problems, it is clear that the public supports a unique role for the military in the context of Turkish politics." ${ }^{23}$ This finding is paradoxical, especially when the conditions under which democratic consolidation thrives are considered. As explained earlier, in consolidated democracies, the tutelage of the military should be undesirable for all significant groups in a society. If the link between support for democratic institutions and confidence in the military can only be explained by the tutelary functions of the armed forces, then it would be clear that trust in the military is a sign of an unconsolidated democracy. Thus, any decrease in public confidence in the armed forces can be perceived as a positive development in terms of democratization.

In conclusion, at first glance, it seems that the Ergenekon investigation had favorable consequences for Turkish democratization. While the civilianization of the regime gained new momentum, the support of the armed forces personnel for democratic rules of the game was attitudinally and behaviorally guaranteed. Moreover, Turkish public opinion regarding the military seemed to change, and, according to Eurobarometer data, confidence in the armed forces decreased to the level of European democracies (69 percent), with possible encouraging effects on democracy. But this is only one side of the coin. A closer examination of public opinion on Ergenekon indeed shows that the trials contributed to polarization in society, which was not conducive to democracy. This is the other side of the coin that will be considered now. 


\section{DEMOCRATIC CONSOLIDATION AND POLARIZATION IN TURKEY}

Few scholars of democratic consolidation would disagree with the argument that polarization in politics is unfavorable to democratic consolidation. ${ }^{24}$ Widespread support for democracy means that there should be consensus among political groups, and especially the elites, on the basic rules of the regime. ${ }^{25}$ Polarization threatens this basic characteristic of a consolidated democracy. It can lead to severe conflicts and radicalization among groups at both the elite and the mass levels. Intense political disagreements, in turn, may result in questioning of the rules of the regime and eschewing of democratic norms and attitudes. ${ }^{26}$ More specifically, as Sani and Segatti argue for the Italian case, polarization might jeopardize two basic values of democracy: “(1) the notion that competition is the very essence of democracy, and (2) recognition that the winner of this competition is rightfully entitled to rule." ${ }^{27}$ The existence of actors who challenge these fundamental elements of democracy makes the regime an unconsolidated one by definition.

Apart from damaging democratic consolidation through attitudinal change, polarization also alters the behaviors of the actors. As a result of polarization, actors might see a risk to their interests, not commit to the regime, and sustain antidemocratic exit options. ${ }^{28}$ In other words, when conflict is intense, actors "look for other, frequently illegal and antidemocratic ways to shore up their positions, engaging in democratic processes only as long as such activities are useful in advancing their interests. ${ }^{29}$ Centrifugal tendencies breed more conflict, as rival groups mutually suspect each other's intentions and question their commitment to democracy. Thus, as the government (or one group) attempts to suppress the opposition (or the rival group), the end result is a vicious circle of continuing polarization. ${ }^{30}$ In fact, such spirals of polarization could even contribute to the collapse of a democratic regime altogether. ${ }^{31}$ 
Turkish democracy broke down several times as a result of intense conflicts among political groups after the transition to multiparty politics in 1946. The CHP ruled as a single party for 23 years, until 1950, when the Democratic Party (DP) won the elections, peacefully changing the regime from an authoritarian to a democratic one. Although authoritarianism never returned to Turkey again, polarization in politics led to violence and military coups. In 1960 and 1980, the Turkish military staged overt coups, and in 1971 and 1997, it forced governments out of power. While in 1960, polarization between the ruling DP and the main opposition CHP tore down democracy, in 1971 and 1980, conflict among leftist and rightist groups led to the collapse of the regime. Indeed, polarization has been an important characteristic of Turkish politics, in part explaining the failure of democracy to consolidate. ${ }^{32}$

In terms of the four cleavages identified by Lipset and Rokkan in their model for European democracies, ${ }^{33}$ Turkey historically never experienced an intense conflict between the urban and rural elites (or the landed nobility and the burghers), in part because of the small landholding pattern in Anatolia. The second cleavage in the Lipset and Rokkan model, namely, that between worker and employer interests, became pronounced in the 1960s and 1970s, but after the 1980s, this cleavage lost its dominance. From the 1990s until 2012, divergence along two other lines, namely, secularism versus religious conservatism and Turkish versus Kurdish nationalism, dominated politics. ${ }^{34}$ In the Lipset and Rokkan model, the former cleavage could be defined as the "conflict between the centralizing, standardizing, and mobilizing Nation-State and the historically established corporate privileges of the Church. ${ }^{\prime 35}$ Even though there is no church in Islam, this cleavage still applied to Turkey once it is considered that the main issue in this cleavage $\mathrm{d}$ been "one of morals, of the control of community norms ... [and most importantly] on the control of education." ${ }^{\prime 36}$ These issues $\mathrm{d}$ been the primary dividing line between religious 
and secular groups in Turkey since the foundation of the nation-state. The state during the singleparty era introduced secular principles in political and social life, which led to conflictual relations between the state elites and religious groups, with various degrees of intensity in the upcoming years. In the multiparty period, political parties emerged aiming to explicitly represent religious interests.

Since the founding of the nation-state, the military had been a central player in this cleavage, claiming to protect the secular foundations of the republic and taking action against pro-Islamist parties. ${ }^{37}$ The armed forces justified their military interventions in part by the favors that political parties gave to Islamic currents. In 1997, the pro-Islamist Welfare Party (Refah Partisi, RP) and its coalitional partner, the True Path Party, were forced out of the government by the pressure of the military. ${ }^{38}$ In the subsequent years, the RP and its heir, the Virtue Party (Fazilet Partisi, FP), were closed down by the Constitutional Court on charges of violating the constitution and engaging in activities against secularism.

After the closure of the FP, the movement split into two factions. ${ }^{39}$ The more moderate group of politicians founded the AKP in August 2001, which received the largest vote share in the 2002 elections. The party renewed its mandate to rule in the 2007 and 2011 elections. Although the leaders of the party had at times claimed that the AKP did not carry out politics based on religion, given that it was descended from organizations that were closed down because of their activities against secularism, there was considerable suspicion that the AKP had an ulterior motive, which was to turn Turkey into an Islamic republic. ${ }^{40}$ Since the 2002 elections, the secularists have been represented in parliament by the main opposition CHP. The CHP is the party that founded the republic in 1923, ruled singlehandedly for more than 20 years, and since then, despite changes in its ideology, has defended secularist principles. Studies examining the 
bases of support for the AKP and CHP in the early 2000s show that the voters of the two parties were distinguished from each other by their stance on the pro-Islamist versus secularist cleavage. ${ }^{41}$ Even though the voter bases of the AKP and the CHP could not be reduced only to this issue, ${ }^{42}$ both in terms of their ideologies and bases of support, the two parties represented two ends of the political spectrum, with the CHP being the main party of the secularist camp and the AKP being the leading party of the pro-Islamist camp.

The second cleavage that had dominated politics since the 1980 coup is based on ethnicity, which polarizes Turkish and Kurdish nationalists. This is the cleavage that Lipset and Rokkan refer to as the "conflict between the central nation-building culture and the increasing resistance of the ethnically, linguistically, or religiously distinct subject populations in the provinces and the peripheries." ${ }^{43}$ This divergence in politics matches the territorial dimension of the national cleavage structure and a center versus periphery conflict. In the Turkish context, similar to the pro-Islamist versus secularist cleavage, this issue went back several decades in Turkish politics, its antecedents lying in the creation of the Turkish nation-state in the 1920s. The visibility of Kurdish separatism increased substantially in the 1980s with the rise of the activities of the Kurdistan Workers' Party (Partiya Karkerên Kurdistan, PKK). ${ }^{44}$ Again, similar to the secularist versus pro-Islamist cleavage, the military had been a dominant player in this issue area as well. The combat against Kurdish separatism in the southeastern regions had been led primarily by the Turkish armed forces since the 1980 s.

In the political arena, the polarization between Kurdish and Turkish nationalists was visible along party lines. Although Kurdish voters supported various parties, including the AKP, the voters of the Peace and Democracy Party (Barış ve Demokrasi Partisi, BDP) were mostly of Kurdish origin. Founded in 2008 and dissolved in 2014, the BDP was the heir to several parties 
that were closed down by the Constitutional Court because of their links with the PKK and their activities against the indivisibility of the Turkish state. Although the primary party of Turkish nationalism was traditionally the Nationalist Action Party (Milliyetçi Hareket Partisi, MHP), ${ }^{45}$ there is evidence to suggest that nationalists also voted for other parties, including the AKP.

Once the party system between 2002 and 2012 is analyzed, it is clear that Turkish politics was polarized along pro-Islamist versus secularist and the Turkish versus Kurdish nationalist cleavages. Public opinion surveys also corroborated the existence of polarization along these lines, and there was a social cleavage that juxtaposed "us" (meaning Turkish, Muslim, and Sunni jointly) against "others" (meaning Kurdish, non-Sunni-that is, mostly Alevi and non-Muslim separately). ${ }^{46}$ The two dominant cleavages could be perceived as crosscutting ones, dividing Turkish politics into four quadrants, namely, Turkish pro-Islamist, Turkish secularist, Kurdish pro-Islamist, and Kurdish secularist. The majority of the population seemed to be located in the Turkish pro-Islamist quadrant, as both religiosity and nationalism were important components of Turkish conservatism. ${ }^{47}$ However, considerable segments of the public could also be placed in the secularist and Kurdish ends of the two separate cleavage lines. The AKP represented those who identified themselves in the Turkish pro-Islamist quadrant, but it also gathered votes from pro-Islamists of Kurdish origin. The MHP got votes from Turkish nationalists of both religious and secular convictions, while the CHP represented primarily Turkish secularists. The BDP stood for the Kurdish nationalists and, as such, primarily drew its support base from Kurdish secularists. Although public opinion was divided along these lines, the political leadership of the parties was located at the more extreme ends of the two cleavages, influencing the public and leading to further polarization. 


\section{POLARIZATION AMONG THE PUBLIC DUE TO THE ERGENEKON CASE}

Once the centrifugal characteristics of Turkish politics are considered, it is no surprise that the Ergenekon investigationwas interpreted differently by the AKP and the opposition. Among the national press, intellectuals, and civil society groups, there was considerable controversy over the inquisition and the court case. ${ }^{48}$

More specifically, there were three interrelated issues of tension between the supporters of the trials and those who raised concerns. ${ }^{49}$ The first disagreement was over the existence of the Ergenekon terrorist organization and whether the accused individuals were in fact guilty. Although the indictments consisted of thousands of pages, opposition groups believed that they had not proved the existence of a clandestine organization beyond a reasonable doubt. Moreover, the individuals who had been charged with being members of Ergenekon were not only military officers but also others coming from diverse backgrounds, such as journalism, academia, civil society, and business. The seemingly unconnected past experiences of the individuals led to doubts over whether they could have been operating as part of the same organization. ${ }^{50}$

The second argument against Ergenekon was related to the legal procedures that were being followed by the prosecutors and the police.$^{51}$ Besides the peculiarities of the Ergenekon case itself, this controversy was also attributable to the endemic problems of the Turkish judiciary. Despite attempts to reform the judiciary in the last decade, it is still a cumbersome institution, which is viewed by international as well as Turkish experts as slow in making decisions and dependent on the executive and the ruling party of the day; in addition, judges and prosecutors pay disproportionate attention to the security of the state rather than individual rights and freedoms. ${ }^{52}$ The Ergenekon case was not an exception to these inherent problems. As in most judicial cases in Turkey, the process moved slowly, and the trials were concluded after 
almost five years. According to a number of critiques, the proof that was provided to accuse these individuals was fictitious, and the long duration of the trials kept innocent people in prison based on fabricated evidence. The problems were compounded because some of the suspects were imprisoned at the beginning of the investigation without being formally charged for months, and a few individuals with medical problems were detained, which resulted in the worsening of their health conditions.

Finally, there was considerable debate among the Turkish public as to whether the AKP government was using the Ergenekon case to its advantage to round up opponents to its rule. Although the AKP was elected to power for three consecutive terms since 2002, the opposition believed that the party had become increasingly authoritarian and gradually tightened its grip on critics. The structural flaws of the judiciary, which led it to depend on the executive, were compounded in the Ergenekon case by the fact that the accused individuals were from various backgrounds and were known to have opposed the AKP. There was a belief in secular circles that the AKP had a religious and antidemocratic agenda, which gave credibility to accusations that the true purpose of the trials and the arrests was to eliminate the secular opposition. ${ }^{53}$ Because an overwhelming number of the accused individuals were well-known secular activists, the arrests of the officers and the Ergenekon trials were perceived as attacks against the guardians of secularism. ${ }^{54}$

The Ergenekon case brought about controversies in public and between the government and opposition. In a setting in which polarization had already made its mark in politics, opinions on the coup allegations are expected to run parallel to the two cleavage lines identified earliersecularist versus pro-Islamist and Turkish versus Kurdish. Therefore, the following analysis tests 
the hypothesis that the Ergenekon case contributed to polarization and matches the conflict especially between the AKP and the opposition parties.

\section{SURVEY DATA AND VARIABLES}

In order to test the hypotheses that opinion on the Ergenekon investigation was in accord with the polarization in society, this article uses the Survey on Armed Forces and Society in Turkey (SAFST) data, which are based on interviews conducted with close to 3,000 individuals in October 2011. The sample for the survey was determined by using the method of stratified multistage sampling design. In the first stage, primary sampling units (PSUs) were determined by the population sizes and the demographic characteristics (education level and density) of districts based on the Address-Based Population Registration System data of the Turkish Statistical Institute (TURKSTAT). In the second stage, these PSUs were grouped into 12 strata, in accordance with the geographic classifications used also by TURKSTAT. Finally, 154 PSUs were randomly selected by a computer program, and 18 individuals were surveyed per sampling unit. Under the assumption of simple random sampling, the size of the sample would have a 2 percent margin of error at a 95 percent confidence level.

The SAFST posed questions measuring economic, political, sociological, ideological, ethnic, religious, and conjectural factors that could be utilized as independent variables - factors that might have caused differences of opinion toward Ergenekon. Table 4 lists the questions from the survey that were used to operationalize the independent variables. The dependent variable, attitudes toward the Ergenekon case, was measured by the SAFST question asking the respondents to agree, somewhat agree, or disagree with the statement, "I believe that the Ergenekon terrorist organization exists." The descriptive statistics of the dependent variable are 
displayed in Table 1. According to the SAFST, while close to half of the respondents (49 percent) agreed that the Ergenekon terrorist organization existed, a significant number disagreed and asserted that they believed that such an organization did not exist.

\section{[Insert Tables 1 and 2 about here]}

When the results are compared among respondents who voted for different parties in the 2011 elections, it is clear that there was a difference of opinion in Turkish society with regard to Ergenekon (see Table 2). Around 65 percent of the respondents who said that they had voted for the AKP agreed with the statement that the "Ergenekon terrorist organization exists." This result contradicts sharply those who said that they had voted for the main opposition, the CHP. Approximately the same proportion of CHP voters (67 percent) disagreed with the same statement, demonstrating the skepticism of the supporters of the opposition about the case. It is not discernible from descriptive statistics whether the MHP and BDP voters were more likely to think positively or negatively of the case. However, the sharp contrast between the AKP and CHP supporters implies that some of the controversies regarding Ergenekon affected and divided the general public's opinion. In order to test the same conclusion by controlling for demographic and other political variables, a statistical model was devised by using the software Stata/SE. Ordinal logistic regression was utilized as a methodology, as an ordinal categorical scale was used to measure the dependent variable with the assumption that the categories could be ordered but the distances between them are not equal. ${ }^{55}$

\section{ANALYSIS AND FINDINGS}

Table 3 provides an analysis of belief in the existence of the Ergenekon terrorist organization by using the ordinal logistic regression model. The ancillary parameters $\left(\tau_{1}\right.$ and $\tau_{2}$ in the model) 
indicate that respondents who had a value of -0.66 or less on the underlying latent variable that gave rise to belief in Ergenekon would be classified as "disagree" when all other variables are evaluated at zero. Analogously, respondents who had a value between -0.66 and 0.24 on the latent variable would be classified as "somewhat agree," and those who had a value of 0.24 or above would be classified as "agree" when all other variables have the value of zero. The $t$-test shows that these two cut points are statistically significant at the 1 percent level of significance. [insert Table 3 about here]

The results of the model reinforce the findings based on analyses of Turkish politics and the descriptive statistics identified earlier. Indeed, the model in Table 3 suggests that there was polarization among the public on Ergenekon, running especially along the lines of secularist versus Islamist cleavage and splits in party politics. As with every analysis based on regression models, it is not possible to make a causal argument based on these results. In other words, the model does not tell us whether the Ergenekon case caused polarization among the supporters of different parties or ideologies. Similarly, because we do not have any comparable data collected over time, it is also not possible to comment on whether polarization in society had increased since the early 2000s as a result of the Ergenekon case. What the regression analysis tells us, however, is that divisions in public opinion regarding the coup allegations were parallel to sharp cleavages that existed in Turkish politics between 2002 and 2012. Thus, in some respects, the Ergenekon trials contributed to already existing centrifugal tendencies, or at least they did not help in annihilating political divisions.

The model in Table 3 excludes the AKP voters as a category among the party vote dummy variables. Thus, estimated results must be interpreted in contrast to AKP voters. This allows a comparison between the voters of all other party supporters and the governing party and 
makes it possible to observe whether opposition party voters perceived the investigation differently than the followers of the AKP. As expected, the model in Table 3 demonstrates that casting a ballot for the CHP in the 2011 elections decreased the likelihood of believing in the Ergenekon organization compared with the AKP voters, holding all other variables constant. The results for the MHP voters are also significant in the model, which is somewhat unexpected, as the descriptive table did not indicate that the majority of the nationalist party supporters had specific attitudes toward Ergenekon one way or another. However, regression analysis is useful for the purposes of examining how the outcome that we are interested in changes when one of the predictors varies when all other factors are held constant. Thus, the regression model gives a more accurate account of the perceptions of the MHP voters toward Ergenekon and indicates that the likelihood of MHP supporters having negative perceptions of the investigation was higher in comparison with the AKP voters. The model also shows that those who voted for political parties other than the four represented in parliament were also suspicious of Ergenekon.

Moreover, those who had a leftist ideology were less likely to have positive perceptions of the trials than those who had center or right-wing outlooks. Among those respondents who identified themselves as having left or center-left ideologies, the likelihood of believing in the existence of Ergenekon was lower (see Table 4 for the exact question that was asked in the survey). There are two reasons why being a leftist was chosen as a predictor variable in the model rather than adherents to other ideologies. First, a significant number of the survey respondents claimed that they did not identify with any of the ideologies on the left-versus-right spectrum (993 out of 2,773). This made it impractical to use the whole scale as a predictor variable. Second, it can be assumed that the AKP and the MHP represented right-wing voters, and therefore those who had center-right and right outlooks were captured by the model. 
However, the same kind of match with left-wing voters and a political party did not exist. Arguably, the CHP represented the left of center in Turkish politics, but despite the fact that some leftists might have voted for the CHP, the fit between the ideology of the party and leftism is questionable. ${ }^{56}$ The party claimed to adhere to the main principles of social democracy in its program, but the ideology of the party still stressed the six principles adopted during the 1920s and 1930s, including nationalism and secularism. ${ }^{57}$ In the 1970s, under the leadership of Bülent Ecevit, the party claimed to represent the working classes and took on a leftist ideology. However, under the leadership of Deniz Baykal, who served as the chair of the party between 1992 and 2010, the image of the party became increasingly elitist and status quo oriented. In the summer of 2008, for instance, there was speculation that the Socialist International would expel the CHP from membership, leading to public discussions about why the CHP did not represent the left or social democracy ${ }^{58}$ Thus, with the assumption that some of those who had leftist ideologies were not reflected in the regression model by party votes, this ideological tendency was included as a predictor variable.

When the results of the regression model are considered, it becomes clear that various groups in the opposition (whether they voted for parties other than the AKP or had leftist ideologies) were not convinced that the Ergenekon accusations were genuine and thought that the claims rested on fabricated evidence. This finding implies that the negative statements of the MHP and CHP leaders on Ergenekon found resonance among some segments of the public. Since the start of the investigation, MHP leader Devlet Bahçeli and other members of the party had criticized developments in Ergenekon and denounced the case from the angle of the damage it inflicted on the armed forces. The party is traditionally promilitary because of its nationalist ideology and values the status, honor, and reputation of the armed forces. The MHP condemned 
the Ergenekon case mostly from this ideological position and regarded it as an unfortunate incident that jeopardized the prestige of the military. ${ }^{59}$ Although the comments of party leadership on the case were infrequent and made not in a manner that directly accused the governing party, nevertheless, it is clear that these statements were still important in shaping public opinion on the matter.

Unlike the MHP leadership, since the beginning of the investigation and under the leadership of Deniz Baykal, the official line of the CHP had been consistently critical of the case and the government. The party questioned the existence of an organization named Ergenekon and accused the AKP of controlling the inquisition and the legal process in order to eliminate its rivals. Under its new leader, Kemal Kılıçdaroğlu, after 2010, the CHP continued to maintain the same position. Kılıçdaroğlu argued that the AKP was creating an "empire of terror," ${ }^{60}$ repressing and censoring the press, ${ }^{61}$ and infringing on the rule of law and establishing a system based on the "law of the rulers." 62 The party leadership also agreed with critics who questioned the existence of the Ergenekon terrorist organization. In a statement belittling the whole process and signifying his skepticism, Kılıçdaroğlu bluntly stated that he wanted to become a member of the organization but did not know where to apply because he could not find its headquarters. ${ }^{63}$

Because the AKP voters were the category that was excluded from the regression model as a predictor, one can conclude that people who voted for the ruling AKP in 2011 were more likely to have positive attitudes toward the investigation when compared with the voters of the opposition parties. This result goes hand in hand with the position the government took on the investigation and the manner in which it defended itself against criticisms involving the AKP's conduct. The official policy of the AKP on Ergenekon emphasized that the investigation was not controlled by the government and that the judiciary and police forces were acting on their own. 
Indeed, Prime Minister Recep Tayyip Erdoğan criticized the opposition for attempting to interfere in the judicial process. ${ }^{64}$ The party maintained that it upheld the rule of law and therefore chose not to meddle with the process ${ }^{65}$ Although in the later stages of the trials, Erdoğan made statements that empathized with the arrested officers and urged a swift court decision ${ }^{66}$ since the beginning of the investigation, implicit in the discourse of the AKP was the belief that the suspects were guilty. This inherent conviction was perhaps not surprising, as the accused individuals were being charged with planning coups against the AKP government. Following the arrests of journalists under the Ergenekon investigation in 2011, for instance, the AKP leadership insisted that the reporters were held in prison because of their involvement in possible coup plots and terrorism. ${ }^{67}$

Another salient finding of the regression model is that trust in the police increased the likelihood of belief in Ergenekon. This may be expected, as the police forces played an important role in exposing the coup plots, carrying out the investigation, and arresting the suspects. Those who trusted the police would also think that Ergenekon was real and that the security forces were only doing their jobs by uncovering a terrorist organization. The significance of trust in the police takes on a new meaning, however, once it is considered that according to some of the critiques, the police forces were controlled by the ruling party and that they were deliberately tarnishing the image of the military. Indeed, the issue of whether the police were trustworthy was at the center of the debate on Ergenekon. Thus, the results from the SAFST demonstrate that this dispute had its repercussions in public opinion as well, leading to a divergence of attitude toward the investigation among those who held different perspectives on the police.

As explained earlier, opinions regarding secularism were one of the main political cleavages in Turkey. Table 3 shows that polarization on Ergenekon ran parallel to this cleavage. 
Even though religiosity does not dictate that an individual would also have antisecular opinions, nevertheless, it is important to note that religiosity changed opinions on the court case. Religiosity was measured in the model with the answers respondents gave to the question regarding the frequency with which they performed the prayer (see Table 4 for the exact question wording and coding). The model suggests that among religious individuals who performed the prayer regularly, belief in the existence of Ergenekon was higher.

In order to measure the attitudes of secularist and relatively nonsecularist individuals, the position of respondents on primary and middle school children wearing headscarves in school was used as a predictor variable. In the Turkish political context, the issue of whether schoolchildren could wear the religious turban in school has been a contentious one, juxtaposing relatively secular individuals, who are opposed to the idea because children cannot decide to wear a headscarf independently of their parents, with those who claim that it is part of religious freedom. More than the issue of schoolchildren wearing the turban, the headscarf ban on university campuses has been a major source of controversy in Turkey. However, some in secular circles agree that the headscarf ban in universities should be lifted. Therefore, perspectives on this issue are not a good indicator of secularism. Indeed, some of those who still support the turban ban in higher education do so because of fears that if this ban is lifted, the next step would be to allow the turban in primary schools. ${ }^{68}$ Table 3 demonstrates that, as expected, secularism had significant influence over attitudes toward Ergenekon. Agreeing to the position that schoolchildren can wear the turban in school increased the likelihood of believing in the existence of the terrorist organization. Thus, the evaluation of the findings suggests that while secularist individuals tended to regard the accusations of coup plots as a sham, nonsecularist people had positive opinions toward the trials. These results imply that the divergence of opinion 
on the Ergenekon investigation was closely associated with polarization between the secularists and pro-Islamists.

The same conclusion, however, does not hold with regard to ethnic cleavage. Turkish nationalism did not seem to relate to positive or negative opinions toward the case. It is not possible to deduce statistically significant changes in attitudes toward Ergenekon, either among those who identified themselves as ethnically Kurdish or among those who promoted Kurdish cultural rights such as positive stances toward education in Kurdish. Additionally, voting for the pro-Kurdish BDP did not necessarily have an influence on the point of view about the investigation.

These results indicate that the ambiguous attitude of the BDP toward the case was also reflected among its voters. Given its pro-Kurdish policies, the BDP approached all security organizations and the judiciary with suspicion. As a result, the party's stance on the case was mixed. On the one hand, it approved of the weakening of the political power of the armed forces; on the other hand, it argued that the AKP was using the investigation to eliminate its opposition ${ }^{69}$ The party leaders suggested that the judiciary refrained from dealing with important issues, such as exposing the unsolved murders, torture, and abductions carried out by some officers in the Kurdish-dominated regions. ${ }^{70}$ In general, the BDP believed that the investigation did not go deep enough and did not touch on sensitive issues, such as revealing the political arm of the organization or coming to terms with violations of Kurdish rights. ${ }^{71}$ Despite the fact that ethnic politics in Turkey was closely related to issues involving the military and the role of the armed forces in politics and society, results from the SAFST data suggest that the Ergenekon investigation did not seem to be linked to the Turkish versus Kurdish cleavage. 
Apart from political predictors, several control variables that were used in the model led to important results that are worth mentioning. Demographically, education and gender had an impact on attitudes toward Ergenekon, whereas age, place of residence, and income did not. More specifically, holding all other variables constant, women tended to be more skeptical of the case than men. Additionally, as the years of education that individuals had increased, belief in the existence of the terrorist organization was also expected to increase.

Regression analysis demonstrates that there were divisions in society with regard to the coup allegations and the court case. AKP voters, men, those who trusted the police more, and more religious, relatively nonsecular, and educated citizens tended to believe that the terrorist organization was real. However, CHP and MHP voters, women, those who were skeptical of the police, and nonreligious, secular, leftist, and less educated people were more likely to disagree with the statement that the Ergenekon terrorist organization existed. In important respects, these findings indicate that the polarization among the governing and opposition parties, as well as between secular and pro-Islamist groups, was matched by the divergence of opinion toward Ergenekon.

\section{CONCLUSION}

What were the consequences of the Ergenekon investigation for Turkish democracy? This article has attempted to find an answer to this question. At first glance, it seems that the operation and trials were favorable developments that would cause further democratization. There is evidence suggesting that the Ergenekon investigation led to lower levels of trust in the Turkish military among the public. Such decrease in public confidence in the military could result in democratization because a military stripped of its popularity might find it more difficult to 
intervene in politics and resist reforms that would curtail its political powers. Indeed, in practice, the coup investigations strengthened the AKP government vis-à-vis the military and led to second-wave reforms in civil-military relations in 2010, after the first wave that started in 1999.

Despite this optimistic outlook, the analysis of the SAFST data shows that the Ergenekon trial contributed to polarization in Turkey or did not helpeliminate existing divisions. After the 1990s, there was a growing divide among political party voters, between pro-Islamists and seculars, and between Turkish and Kurdish nationalists. Attitudes toward the Ergenekon investigation paralleled the former two cleavages. Given the different discourses of the party leaders on the trials, it is clear that the Ergenekon case matched the cleavage among AKP and CHP/MHP voters and between the pro-Islamists and seculars.

This type of polarization is not conducive to democratic consolidation. If the model utilized by Linz and Stepan is applied to Turkish democracy, it becomes clear that the Ergenekon case led to behavioral, attitudinal, and constitutional setbacks. ${ }^{72}$ First, essential facilitators of democracy, such as mutual trust among significant groups in society and belief that the other group is also loyal to the regime, are damaged because of polarization. These mutual suspicions may result in antidemocratic activities, such as using repression and looking for exit options. This leads to a situation in which democracy does not get consolidated behaviorally and significant actors turn to violence and try to overthrow the regime in order to achieve their objectives. Under current circumstances, the chances for the unconsolidated democracy of Turkey to break down because of another military coup are low. However, demonstrations that started against the government-supported project of building a shopping mall at Gezi Park in Istanbul's Taksim Square showed how polarization could escalate into violence, with detrimental consequences for democracy. In the summer of 2013, thousands of people in a number of cities 
across Turkey protested against the government for several months. The police attempted to disperse the crowds by using teargas, water cannons, and clubs. While the opposition and the protestors claimed that the police used disproportionate force against peaceful protestors, Prime Minister Erdoğan argued that the events were a conspiracy against the government carried out by several groups, including the CHP and financial interests. ${ }^{73}$ In less than one month following the start of the Gezi events, four people had died, 11 protestors had lost their eyes, and 7,832 had been injured. ${ }^{74}$ Increasing polarization in Turkish politics, to which Ergenekon also contributed, spiraled out of control and brought violence to the streets. As the government used repression, behavioral compliance with democracy deteriorated.

Yet, the consequences of Ergenekon were more nuanced than just the possibility of decreasing behavioral compliance with democracy. Attitudinally, polarization makes it more difficult for elites and public to come together and agree on the basic rules of the game. Continued polarization, further perpetuated by the controversies of the court trials, led to a questioning of the rules of the game, especially among the supporters of the opposition parties and secularists. Although they might not hedge and support an antidemocratic regime behaviorally, they might still abandon democratic norms altogether in the future. Besides, currently, some secular circles call into dispute the existence of the rule of law, the results of the elections, and the legitimacy of the AKP to rule. The governing party, on the other hand, perceives these challenges as antidemocratic attacks and adopts a rhetoric against them, which further increases suspicions that the AKP is repressing the voices of the opposition parties and media. As a result, the number of people who question the basic rules of the game, such as elections and freedom of speech, increases. 
Finally, constitutionally, Turkey still does not have a consolidated democracy. This dimension refers to actors being accustomed to competing within the specific laws and procedures of the regime. The disputes regarding the constitution of Turkey are a good example of how polarization in politics has led to the failure of consolidation in this dimension. Far from abiding by the laws of the country, the government and opposition both advocate the writing of a new constitution, replacing the one that was written during military rule in 1982. The idea of a new constitution, indeed, is a positive development given the antidemocratic elements of the old one. However, the AKP and the opposition parties cannot agree on most of the articles of the constitution. In the parliamentary committee responsible for writing the new constitution, the parties agreed only on 29 articles out of the 150 they discussed in more than one and a half years. ${ }^{75}$ The AKP declared that if the committee could not reach a compromise, then the government would write its own constitution and seek public approval in a referendum. The new AKP constitution is expected to change the system of government from a parliamentary to a presidential one. The opposition forces strictly oppose this system change, arguing that it would lead to an authoritarian regime under the rule of the AKP leadership. ${ }^{76}$ This ongoing debate clearly shows how polarization contributes to the failure of democratic consolidation in Turkey constitutionally.

Currently in Turkey, significant actors do not provide attitudinal support for the rules of the regime, and they cannot agree on the constitution and the basic laws and procedures of the country. Turkey witnessed violence and diminishing behavioral endorsement for the regime, too. Although Ergenekon is not the only factor that contributed to polarization, it is one of the elements that dealt a blow to Turkish democracy. It is true that the annihilation of military coups, the civilianization of the regime, and declining public confidence in the armed forces are 
welcomed consequences of the court case. However, these positive impressions associated with Ergenekon disappear once the negative consequences of the case are analyzed. By cutting deep into the ruptures of Turkish politics while seeming to heal other past injuries, the case had been a double-edged sword for Turkish democracy.*

[Insert Table 4 near end of article]

* I would like to thank Senem Aydın-Düzgit, Emre Erdoğan, Ersin Kalaycığlu, Işık Özel, Soli Özel, William B. Quandt, Sabri Sayarı, and Çağdaş Şirin for their comments and suggestions during the research and writing phases of this article. An earlier draft of this article was published as a working paper by the European Institute of Istanbul Bilgi University.

\section{NOTES}

1 “Ergenekon'un Aritmetiği” [The arithmetic of Ergenekon], Radikal, 7 August 2013.

${ }^{2}$ The survey is part of a project titled "Armed Forces and Society in Turkey: An Empirical Approach," funded by the Scientific and Technological Research Council of Turkey (TÜBITTAK) under the Support Program for Scientific and Technological Research Projects (1001) (Project no. 110K462). The survey was conducted by KONDA Research and Consultancy Company under the supervision of the director of the project, Dr. Zeki Sarigil from Bilkent University, and researcher, Dr. Yaprak Gürsoy from Istanbul Bilgi University.

${ }^{3}$ For definitions of democracy, see Robert A. Dahl, Polyarchy: Participation and Opposition (New Haven, CT: Yale University Press, 1972), 3; Juan Linz, "Totalitarian and Authoritarian Regimes," in Fred I. Greenstein and Nelson W. Polsby, eds., Handbook of Political Science, vol. 3, Macropolitical Theory (Reading, MA: Addison-Wesley, 1975), 182-183; Juan J. Linz, Alfred 
Stepan, and Richard Gunther, "Democratic Transition and Consolidation in Southern Europe, with Reflections on Latin America and Eastern Europe,” in Richard Gunther, P. Nikiforos Diamandouros, and Hans-Jürgen Puhle, eds., The Politics of Democratic Consolidation: Southern Europe in Comparative Perspective (Baltimore: Johns Hopkins University Press, 1995), 78; and Phillipe C. Schmitter and Terry Lynn Karl, "What Democracy Is... and Is Not," Journal of Democracy 2 (Summer 1991): 75-88.

${ }^{4}$ On the conceptualization of civilian control of the military and its significance for democracy, see Aurel Croissant, David Kuehn, Paul Chambers, and Sigfried O. Wolf, "Beyond the Fallacy of Coup-ism: Conceptualizing Civilian Control of the Military in Emerging Democracies," Democratization 17 (October 2010): 950-975.

${ }^{5}$ For various definitions of democratic consolidation, see Adam Przeworski, Democracy and the Market: Political and Economic Reforms in Eastern Europe and Latin America (Cambridge: Cambridge University Press, 1991), 26-34; Richard Gunther, Hans-Jürgen Puhle, and P. Nikiforos Diamandouros, "Introduction," in Gunther, Diamandouros, and Puhle, eds., The Politics of Democratic Consolidation, 1-32; and Juan J. Linz and Alfred Stepan, Problems of Democratic Transition and Consolidation: Southern Europe, South America, and PostCommunist Europe (Baltimore: John Hopkins University Press, 1996), 5-7.

${ }^{6}$ Ümit Cizre-Sakallığlu, "The Anatomy of the Turkish Military’s Political Autonomy,” Comparative Politics 29 (January 1997): 151-166.

${ }^{7}$ On the popularity of the EU since 1996, see Ali Çarkoğlu and Ersin Kalaycığlu, The Rising Tide of Conservatism in Turkey (New York: Palgrave Macmillan, 2009), 122-129.

${ }^{8}$ Several authors explain the acceptance of these reforms by the military by the fact that they were part of EU conditionality. See, for instance, Ersel Aydınlı, Nibat Ali Özcan, and Doğan 
Akyaz, "The Turkish Military's March toward Europe," Foreign Affairs 85 (January-February 2006): 77-90; and Tuba Ünlü Bilgiç, “The Military and Europeanization Reforms in Turkey,” Middle Eastern Studies 45 (September 2009): 803-824.

${ }^{9}$ The amendments in civil-military relations attributable to the EU accession process have been well documented in the literature. See, for example, Yaprak Gürsoy, "The Impact of EU-Driven Reforms on the Political Autonomy of the Turkish Military," South European Society and Politics 16 (June 2011): 293-308.

${ }^{10}$ Ibid., 297-300.

11 Y1lmaz Esmer, "Islam, Gender, Democracy and Values: The Case of Turkey, 1990-2001," in Thorleif Pettersson and Y1lmaz Esmer, eds., Changing Values, Persisting Cultures: Case Studies in Value Change (Boston: Brill, 2008), 291-293.

${ }^{12}$ Results of the World Values Surveys corroborate the finding that confidence in the armed forces declined from 94 percent in 1996 to 75 percent in 2011. "World Values Survey Reveals Important Trends in Turkey," SETimes, 5 August 2011.

${ }^{13}$ Eurobarometer Survey, European Union 1995-2010, accessed at http://ec.europa.eu/public_opinion/cf/index_en.cfm. The results of the Eurobarometer Surveys were compiled by the author from raw data, downloaded from the GESIS Data Archive in Cologne, which provides the newest versions of the original data. There may be small differences from the results that are produced and reported by the Eurobarometer Web site as a result of this difference in versions.

${ }^{14}$ Surveys conducted in 1990 and 1997 also show that the Turkish public had more confidence in the military than on average in European countries. See Y1lmaz Esmer, Devrim, Evrim ve 
Statüko: Türkiye'de Sosyal, Siyasal, Ekonomik Değerler [Revolution, evolution, and status quo: Social, political, and economic values in Turkey] (Istanbul: TESEV Yayınları, 1999), 45.

${ }^{15}$ For analyses of factors influencing public confidence in the military, see ibid., 50; and Zeki Sarıgil, "Deconstructing the Turkish Military's Popularity," Armed Forces and Society 35 (July 2009): 709-727, at 717-721.

${ }^{16}$ The Eurobarometer surveys did not ask the same question again until 2014. In the 2014 survey, trust in the military was lower than the previous results, with 62 percent declaring that they trust the military and 33 percent saying that they do not. The EU average was 70 percent and 20 percent respectively. Eurobarometer Survey, European Union 1995-2010, accessed at http://ec.europa.eu/public_opinion/cf/index_en.cfm.

${ }^{17}$ For a discussion of the changing attitudes among the public and elites toward the armed forces in the 2000s and their possible reasons, see Ersel Aydınl, "A Paradigmatic Shift for the Turkish Generals and an End to the Coup Era in Turkey," Middle East Journal 63 (Autumn 2009): 581596, at 586-587; Nilüfer Narl, "EU Harmonisation Reforms, Democratisation and a New Modality of Civil-Military Relations in Turkey," in Manas Chatterji, ed., Advances in Military Sociology: Essays in Honor of Charles C. Moskos (Bingley, UK: Emerald Group Publishing, 2009), 447-465; Tanel Demirel, 2000'li Yıllarda Asker ve Siyaset: Kontrollü Değişim ile Statüko Arasinda Türk Ordusu [Soldier and politics in the 2000s: Turkish military between controlled change and status quo] (Ankara: Siyaset, Ekonomi ve Toplum Araştırmaları Vakfi, 2010), 8-10; and Yaprak Gürsoy, "The Changing Role of the Military in Turkish Politics: Democratization through Coup Plots?," Democratization 19 (August 2012): 735-760.

${ }^{18}$ Tanel Demirel, "Soldiers and Civilians: The Dilemma of Turkish Democracy," Middle Eastern Studies 40 (January 2004): 128; Sarıgil, “Deconstructing," 711. 
19 Ümit Cizre, "Problems of Democratic Governance of Civil-Military Relations in Turkey and the European Union Enlargement Zone,” European Journal of Political Research 43 (January 2004): 107-25; and Linda Michaud-Emin, "The Restructuring of the Military High Command in the Seventh Harmonization Package and Its Ramifications for Civil-Military Relations," Turkish Studies 8 (March 2007): 25-42.

${ }^{20}$ For a criticism of the argument that the political role of the military in Turkey is attributable to high levels of public trust, see Ahmet Kuru, "The Rise and Fall of Military Tutelage in Turkey: Fears of Islamism, Kurdism, and Communism," Insight Turkey 14 (Spring 2012): 37-57, at 4143.

${ }^{21}$ Mark Tessler and Ebru Altınoğlu, "Political Culture in Turkey: Connections among Attitudes toward Democracy, the Military and Islam,” Democratization 11 (February 2004): 21-50, at 34; and Sarıil, "Deconstructing," 719.

${ }^{22}$ Ergun Özbudun, Contemporary Turkish Politics: Challenges to Democratic Consolidation (Boulder, CO: Lynne Rienner, 2000), 123; Tessler and Altınoğlu, "Political Culture," 34; and Sar1gil, “Deconstructing,” 719-20.

${ }^{23}$ Ali Çarkoğlu and Binnaz Toprak, Religion, Society and Politics in a Changing Turkey (Istanbul: TESEV Publications, 2007), 83.

${ }^{24}$ For an example of the significance attributed to the consequences of polarization for democratic consolidation, see the figure in Michael Burton, Richard Gunther, and John Higley, “An Introduction: Elite Transformation and Democratic Regime,” in John Higley and Richard Gunther, eds., Elites and Democratic Consolidation in Latin America and Southern Europe (Cambridge: Cambridge University Press, 1992), 23.

25 Ibid., 5. 
${ }^{26}$ Leonardo Morlino, "Political Parties and Democratic Consolidation in Southern Europe," in Gunther, Diamandouros, and Puhle, eds., The Politics of Democratic Consolidation, 349, 359. ${ }^{27}$ Giacomo Sani and Paolo Segatti, “Antiparty Politics and Restructuring of the Italian Party System," in Gunther, Diamandouros, and Puhle, eds., The Politics of Democratic Consolidation, 163.

${ }^{28}$ For some examples of what might constitute such exit options and mechanisms of "hedging," see Gerard Alexander, The Sources of Democratic Consolidation (Ithaca, NY: Cornell University Press, 2002), 60.

${ }^{29}$ Gunther, Puhle, and Diamandouros, "Introduction," 10.

30 Ibid.

${ }^{31}$ See, for instance, the collapse of the Greek regime in 1967 and the Pakistani political system in 1999, in Thomas C. Bruneau, P. Nikiforos Diamandouros, Richard Gunther, Arend Lijphart, Leonardo Morlino, and Risa A. Brooks, "Democracy, Southern European Style," in P. Nikiforos Diamandouros and Richard Gunther, eds., Parties, Politics, and Democracy in the New Southern Europe (Baltimore: Johns Hopkins University Press, 2001), 58; and Larry Diamond, The Spirit of Democracy: The Struggle to Build Free Societies throughout the World (New York: Times Books, 2008), 58.

32 Özbudun, Contemporary Turkish Politics, 99.

${ }^{33}$ Seymour Martin Lipset and Stein Rokkan, “Cleavage Structures, Party Systems, and Voter Alignments: An Introduction," in Seymour Martin Lipset and Stein Rokkan, eds., Party Systems and Voter Alignments: Cross-National Perpectives (New York: Free Press, 1967). 
${ }^{34}$ For an overview of Turkish party system polarization, see Ergun Özbudun, Türkiye'de Parti ve Seçim Sistemi [Party and election system in Turkey] (Istanbul: Istanbul Bilgi Üniversitesi Yayınlar1, 2011), 72-79.

${ }^{35}$ Lipset and Rokkan, "Cleavage Structures,” 14.

36 Ibid., 15.

${ }^{37}$ For more on this polarization in public opinion, see the analysis of a 2006 survey in Çarkoğlu and Toprak, Religion, Society and Politics, 32-34, 101.

${ }^{38}$ For the process, see Metin Heper and Aylin Güney, "The Military and the Consolidation of Democracy: The Recent Turkish Experience," Armed Forces and Society 26 (Summer 2000): $635-657$.

${ }^{39}$ On the split of the National Outlook movement and the birth of the AKP, see Fulya Atacan, "Explaining Religious Politics at the Crossroad: AKP-SP,” in Ali Çarkoğlu and Barry Rubin, eds., Religion and Politics in Turkey (New York: Routledge, 2006), 45-57.

${ }^{40}$ William Hale and Ergun Özbudun, Islamism, Democracy and Liberalism in Turkey: The Case of the AKP (New York: Routledge, 2010), 20-29.

${ }^{41}$ On the 1990s, see Ersin Kalaycıoğlu, "Elections and Party Preferences in Turkey: Changes and Continuities in the 1990s," Comparative Political Studies 27 (October 1994): 402-424, at 420421. For more recent survey analyses, see Y1lmaz Esmer, "At the Ballot Box: Determinants of Voting Behavior," in Sabri Sayarı and Y1lmaz Esmer, eds., Politics, Parties, and Elections in Turkey (Boulder, CO: Lynne Rienner, 2002), 105-109; and Çarkoğlu and Toprak, Religion, Society and Politics, 83. The analysis of the 2002 elections by Ali Çarkoğlu and Ersin Kalaycığlu shows that religiosity and issues concerning religious freedoms especially have an 
impact on the AKP and CHP constituents; see Turkish Democracy Today: Elections, Protest and Stability in an Islamic Society (New York: I.B. Tauris, 2007), 190-191, 202-203.

${ }^{42}$ For the voters whom the AKP represents, see Hale and Özbudun, Islamism, Democracy, 37.

${ }^{43}$ Lipset and Rokkan, “Cleavage Structures,”14.

${ }^{44}$ For more information on this issue, see Kemal Kirişçi and Gareth M. Winrow, The Kurdish Question and Turkey: An Example of a Trans-state Ethnic Conflict (London: Frank Cass, 1997); and Henri J. Barkey and Graham E. Fuller, Turkey’s Kurdish Question (Lanham, MD: Rowman \& Littlefield, 1998).

${ }^{45}$ For the indicators of the MHP vote in the 1999 elections, see Esmer, "At the Ballot Box," 109. ${ }^{46}$ Çarkoğlu andToprak, Religion, Society and Politics, 103.

${ }^{47}$ Çarkoğlu and Kalaycıoğlu, The Rising Tide of Conservatism, 35, 47, 52. For previous research, see Esmer, "At the Ballot Box," 97-99; Çarkoğlu and Toprak, Religion, Society and Politics, 101; and Esmer, "Islam, Gender, Democracy, Values," 293-298.

${ }^{48}$ Şule Toktaş and Ümit Kurt, “The Turkish Military’s Autonomy, JDP Rule and the EU Reform Process in the 2000s: An Assessment of the Turkish Version of Democratic Control of Armed Forces (DECAF)," Turkish Studies 11 (September 2010): 387-403, at 397-398.

${ }^{49}$ For an overview of these controversies, see H. Akın Ünver, “Turkey’s 'Deep State' and the Ergenekon Conundrum” (Middle East Institute Policy Brief 23, Middle East Institute, Washington, DC, 2009), 12-14; and Gareth Jenkins, “Between Fact and Fantasy: Turkey’s Ergenekon Investigation" (Silk Road Paper, Institute for Security and Development Policy, Nacka, Sweden, 2009), 78-83.

${ }^{50}$ For such a view, see, for instance, Türker Alkan, “Aşinalık Ne Zaman Aşka Dönüşür?” [When does acquaintance transform into love?], Radikal, 6 July 2008. 
${ }^{51}$ Soli Özel, "The Back and Forth of Turkey’s 'Westernness"” (analysis, German Marshall Fund of the United States, Washington, DC, 2009), 2.

${ }^{52}$ Senem Aydın-Düzgit and E. Fuat Keyman, "EU-Turkey Relations and the Stagnation of Turkish Democracy” (Working Paper 2, Istituto Affari Internazionali, Rome, 2012), 15-17, accessed at http://www.iai.it/pdf/GTE/GTE_WP_02.pdf, 28 January 2013.

${ }^{53}$ See, for instance, Soner Çă̆aptay, “Behind Turkey’s Witch Hunt,” Newsweek, 16 May 2009; and “What's Really behind Turkey's Coup Arrests?," Foreign Policy, 25 February 2010.

${ }^{54}$ Amberin Zaman, “Receding Power of Turkey’s Military: A Leap for Democracy or Another Power Struggle?" (analysis, German Marshall Fund of the United States, Washington, DC, 2009), 2.

55 J. Scott Long, Regression Models for Categorical and Limited Dependent Variables (Thousand Oaks, CA: Sage, 1997), 114-116; and Scott Menard, Applied Logistic Regression Analysis (Thousand Oaks, CA: Sage, 2002).

${ }^{56}$ For the ideology of the party, see Ayşe Güneş Ayata, "The Republican People's Party," Turkish Studies 3 (February 2002): 102-121.

57 “Çağdaş Türkiye için Değişim: Cumhuriyet Halk Partisi Programı” [Change for modern Turkey: The program of the Republican People's Party], accessed at http://www.chp.org.tr/en/wp-content/uploads/chpprogram.pdf, 24 January 2013. ${ }^{58}$ See, for instance, Zülfü Livaneli, “CHP'nin Solla Ne İlgisi Var?” [What does the CHP have to do with the left?], Vatan, 30 June 2008; Nazlı Ilıcak, “CHP Solcu Mu, Sağc1 M1?” [Is the CHP leftist or rightist?], Sabah, 1 July 2008; and Mehmet Altan, “Baykal Neden Gidemedi?” [Why could Baykal not go?], Star, 30 June 2008. 
${ }^{59}$ For such a statement, see, for example, "MHP: Cumhurbaşkanı Göreve” [MHP: President, report for duty], Radikal, 4 July 2008.

60 “Bask1lar Halkı Patlatır” [Pressures would burst the public], Hürriyet, 15 February 2011.

61 “Kılıçdaroğlu’ndan Savcılara: Hesap Vereceksiniz” [From Kılıçdaroğlu to the prosecutors: You will be brought to account], Radikal, 11 March 2011.

62 “Üstünlerin Hukuku” [The law of the rulers], Hürriyet, 13 February 2011.

63 "Nerede Bu Örgüt Üye Olayım" [Where is this organization, let me be a member], Hürriyet, 16 February 2011.

64 “‘Nerede Bu Örgüt Üye Olacağım’ Sözü Yargıya Müdahale” [The statement 'where is this organization, i will be a member' is an intervention to the judiciary], Hürriyet, 17 February 2011. 65 "Yargıya Başbakan Bile Telkinde Bulunmamalı" [Even the prime minister should not make suggestions to the judiciary], Hürriyet, 17 February 2011; "Yargının Tasarrufu Bize Çamur Atmayın" [Judiciary’s authority, do not slander us], Akşam, 5 March 2011.

${ }^{66}$ See, for example, "Bakanlıklar Kalıcı Makam Değildir" [The post of minister is not a permanent one], Milliyet, 26 January 2013.

67 “Gazeteci Kılıklı Kişiler İçin Ayağa Kalktılar” [They are revolting for people who appear to be journalists], Hürriyet, 14 March 2011; and "Sistematik Karalama Kampanyası" [Systematic slander campaign], Hürriyet, 15 March 2011.

${ }^{68}$ Murat Boroval,, "Islamic Headscraves and Slippery Slopes," Cardozo Law Review 20 (June 2009): 2593-2611, at 2601-2605. See also the position of the CHP leader on this issue in Fikret Bila, “Kılıçdaroğlu’nun Beklediği Mesaj Köşk’ten Geldi” [The message that Kılıçdaroğlu was waiting for came from the villa], Milliyet, 11 November 2010. 
69 “DTP de Tepkili: Ergenekon AKP Karşıtlarına Yöneldi” [The DTP is also reactive: Ergenekon has been directed against AKP opponents], Radikal, 14 April 142009.

70 "DTP: Savc1, Ergenekon Soruşturmasını Magazinselleştiriyor" [The DTP: The prosecutor is making the Ergenekon investigation a magazine show], Radikal, 26 March 2009.

71 “BDP: Darbe Planlandıysa Siyasi Ayağı da Ortaya Çıkarılmalı” [The BDP: If a coup was planned, its political leg should also be revealed], Radikal, 2 March 2010.

${ }^{72}$ Linz and Stepan, Problems of Democratic Transition and Consolidation, 5-6.

${ }^{73}$ Illter Turan, “Encounters with the Third Kind: Turkey’s New Political Forces Are Met by Old Politics" (analysis, German Marshall Fund of the United States, Washington, DC, 2013).

74 “Gezi Parkı Bilançosu: 4 ölü 60’’ ağır 7832 yaralı” [The balance sheet of the Gezi Park: 4 dead, 7832 injured including 60 seriously wounded], Hürriyet, 21 June 2013.

75 "Yeni Anayasada Kritik Viraj" [A critical turning point in the new constitution], Vatan, 28 April 2013.

${ }^{76}$ Fuat Keyman, "Başkanlık Sistemi” [Presidential system], Milliyet, 10 April 2013. 


\section{FIGURE 1}

Trust in the Army in Turkey and EU Member States

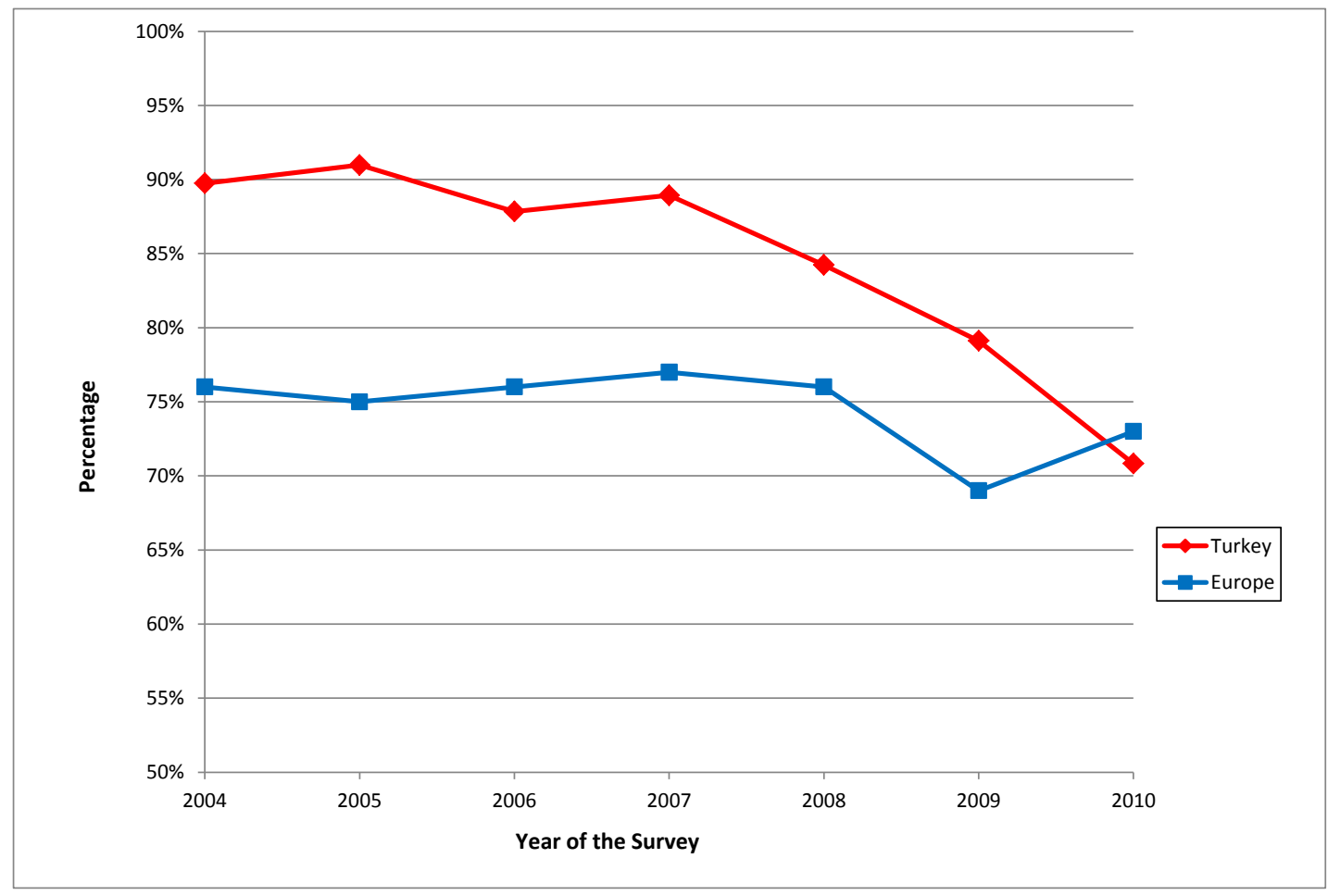

Source: Compiled by the author from European Commission (2011-2013): Eurobarometer 62.0, 64.2, 66.1, 68.1, 69.2, 72.4, 74.2. TNS OPINION \& SOCIAL, Brussels [Producer]. GESIS Data Archive, Cologne. ZA4229 Data file Version 1.1.0, ZA4414 Data file Version 1.1.0, ZA4526 Data file Version 1.0.1, ZA4565 Data file Version 4.0.1, ZA4744 Data file Version 4.0.0, ZA4994 Data file Version 3.0.0, ZA5449 Data file Version 2.2.0.

Note: Frequencies in the graph were calculated without the "don't know" answers. 
TABLE 1

Belief in the Existence of Ergenekon

\begin{tabular}{|l|c|c|}
\hline & $\begin{array}{c}\text { Number of } \\
\text { Respondents }\end{array}$ & Percent \\
\hline Disagree & 871 & 33.59 \\
\hline Somewhat agree & 461 & 17.78 \\
\hline Agree & 1,261 & 48.63 \\
\hline TOTAL & 2,593 & 100.00 \\
\hline
\end{tabular}

Source: SAFST.

TABLE 2

Descriptive Statistics: Party Vote and Attitudes toward Ergenekon

\begin{tabular}{|c|c|c|c|c|}
\hline \multirow[b]{2}{*}{$\begin{array}{c}\text { Party Vote } \\
\text { in } 2011 \\
\text { Elections }\end{array}$} & \multicolumn{4}{|c|}{ Belief in the Existence of Ergenekon } \\
\hline & Disagree & $\begin{array}{c}\text { Somewhat } \\
\text { Agree }\end{array}$ & Agree & Total \\
\hline $\begin{array}{c}\text { AKP } \\
\text { (percent) }\end{array}$ & $\begin{array}{c}222 \\
(18.12)\end{array}$ & $\begin{array}{c}202 \\
(16.49) \\
\end{array}$ & $\begin{array}{c}801 \\
(65.39) \\
\end{array}$ & $\begin{array}{c}1,225 \\
(100.00)\end{array}$ \\
\hline $\begin{array}{c}\text { CHP } \\
\text { (percent) }\end{array}$ & $\begin{array}{c}355 \\
(67.11)\end{array}$ & $\begin{array}{c}79 \\
(14.93)\end{array}$ & $\begin{array}{c}95 \\
(17.96)\end{array}$ & $\begin{array}{c}529 \\
(100.00)\end{array}$ \\
\hline $\begin{array}{c}\text { MHP } \\
\text { (percent) }\end{array}$ & $\begin{array}{c}79 \\
(39.11)\end{array}$ & $\begin{array}{c}37 \\
(18.32)\end{array}$ & $\begin{array}{c}86 \\
(42.57)\end{array}$ & $\begin{array}{c}202 \\
(100.00)\end{array}$ \\
\hline $\begin{array}{c}\text { BDP } \\
\text { (percent) }\end{array}$ & $\begin{array}{c}22 \\
(21.78)\end{array}$ & $\begin{array}{c}25 \\
(24.75)\end{array}$ & $\begin{array}{c}54 \\
(53.47)\end{array}$ & $\begin{array}{c}101 \\
(100.00)\end{array}$ \\
\hline $\begin{array}{l}\text { Other party } \\
\text { voters } \\
\text { (percent) }\end{array}$ & $\begin{array}{c}20 \\
(29.85)\end{array}$ & $\begin{array}{c}10 \\
(14.93)\end{array}$ & $\begin{array}{c}37 \\
(55.22)\end{array}$ & $\begin{array}{c}67 \\
(100.00)\end{array}$ \\
\hline $\begin{array}{c}\text { Total } \\
\text { (percent) }\end{array}$ & $\begin{array}{c}698 \\
(32.86)\end{array}$ & $\begin{array}{c}353 \\
(16.62)\end{array}$ & $\begin{array}{c}1,073 \\
(50.52)\end{array}$ & $\begin{array}{c}2,124 \\
(100.00)\end{array}$ \\
\hline
\end{tabular}

Source: Author's own calculations based on SAFST data. 
TABLE 3: Ordinal Logistic Regression Model of Belief in the Existence of the Ergenekon Organization

\begin{tabular}{|c|c|}
\hline Predictors & Coefficient (standard errors) \\
\hline \multicolumn{2}{|l|}{ Demographic variables: } \\
\hline Age & $\begin{array}{l}-0.0044885 \\
(0.0040335)\end{array}$ \\
\hline Education & $\begin{array}{c}0.0336967 * * \\
(0.014993)\end{array}$ \\
\hline Place of residence & $\begin{array}{c}0.0313683 \\
(0.0617427)\end{array}$ \\
\hline Gender & $\begin{array}{c}-0.3734342 * * * \\
(0.1003311)\end{array}$ \\
\hline Income & $\begin{array}{c}0.0000364 \\
(0.0000443)\end{array}$ \\
\hline \multicolumn{2}{|l|}{ Party vote in the 2011 national elections: } \\
\hline Republican People's Party (CHP) & $\begin{array}{c}-1.601729 * * * \\
(0.157529)\end{array}$ \\
\hline Nationalist Action Party (MHP) & $\begin{array}{c}-0.7969605 * * * \\
(0.1570459)\end{array}$ \\
\hline Peace and Democracy Party (BDP) & $\begin{array}{l}-0.1773047 \\
(0.2979115)\end{array}$ \\
\hline Other party voters & $\begin{array}{l}-0.519841^{*} \\
(0.2714714)\end{array}$ \\
\hline Leftist & $\begin{array}{c}-0.4398283 * * * \\
(0.1630306)\end{array}$ \\
\hline Trust in the police & $\begin{array}{l}0.3161062 * * * \\
(0.067903)\end{array}$ \\
\hline \multicolumn{2}{|l|}{ Ethnicity and nationalism: } \\
\hline Turkish nationalism & $\begin{array}{l}-0.0895901 \\
(0.0860979)\end{array}$ \\
\hline Kurdish ethnicity & $\begin{array}{c}0.0727053 \\
(0.2008894)\end{array}$ \\
\hline Position on Kurdish language rights & $\begin{array}{l}-0.0000763 \\
(0.0601488)\end{array}$ \\
\hline \multicolumn{2}{|l|}{ Secularism and religiosity: } \\
\hline Religiosity & $\begin{array}{c}0.3628578 * * * \\
(0.1095689)\end{array}$ \\
\hline $\begin{array}{l}\text { Position on primary and middle school } \\
\text { children wearing headscarves }\end{array}$ & $0.3695888 * * *$ \\
\hline & $(0.0574409)$ \\
\hline $\begin{array}{l}\tau_{1} \\
\tau_{2}\end{array}$ & $\begin{array}{c}-0.6621995^{* *} \\
(0.313926) \\
0.2405337 \\
(0.3133246) \\
\end{array}$ \\
\hline Observations & 1,979 \\
\hline $\operatorname{LR} \chi^{2}(16)$ & 573.00 \\
\hline Prob $>\chi^{2}$ & 0.0000 \\
\hline Pseudo $R^{2}$ & 0.1435 \\
\hline
\end{tabular}

Source: Author's own calculations based on SAFST data. Note: The excluded categories are the AKP voters and 
those who reside in rural areas.

$* * * p<.01 ; * * p<.05 ; * p<.1$.

TABLE 4

SAFST Questions and Coding

\begin{tabular}{|c|c|c|}
\hline Variables & $\begin{array}{l}\text { Survey Question Numbers, } \\
\text { Questions, and Coding }\end{array}$ & Codes Used in the Model \\
\hline Gender & Q1. The gender of the respondent & $\begin{array}{l}\text { Female: } 1 \\
\text { Male and no answer: } 0 \\
\end{array}$ \\
\hline Age & Q2. How old are you? & $\begin{array}{l}\text { Continuous from } 17 \text { to } 86 \\
\text { (Even though the respondents } \\
\text { should have been } 18 \text { years old } \\
\text { or older, in the final survey } \\
\text { data, there were two } \\
\text { respondents who were age } 17 \text { ) }\end{array}$ \\
\hline Education & $\begin{array}{l}\text { Q3. What is your educational status, } \\
\text { in other words, what is the level of } \\
\text { school you last finished? }\end{array}$ & $\begin{array}{l}\text { Illiterate: } 0 \\
\text { Literate with no diploma: } 1 \\
\text { Primary school graduate: } 5 \\
\text { Middle school graduate: } 8 \\
\text { High school graduate: } 11 \\
\text { University graduate: } 15 \\
\text { Graduate school: } 17\end{array}$ \\
\hline $\begin{array}{l}\text { Party vote in the } \\
2011 \text { national } \\
\text { elections }\end{array}$ & $\begin{array}{l}\text { Q12. Who, which party did you vote } \\
\text { for in the } 12 \text { June general deputyship } \\
\text { elections? }\end{array}$ & $\begin{array}{l}\text { Dummy variables were } \\
\text { created for the AKP, CHP, } \\
\text { MHP, BDP, and other party } \\
\text { voters }\end{array}$ \\
\hline Leftist & $\begin{array}{l}\text { Q14. In terms of politics, there has } \\
\text { been a right, left, center tradition in } \\
\text { Turkey for many years. Where } \\
\text { would you identify yourself in terms } \\
\text { of political outlook? } \\
\text { Left; Center left; Center; Center } \\
\text { right; Right; None }\end{array}$ & $\begin{array}{l}\text { Left or center left: } 1 \\
\text { Others: } 0\end{array}$ \\
\hline Turkish nationalism & $\begin{array}{l}\text { Q15. What is the extent to which } \\
\text { you would describe yourself as a } \\
\text { Turkish nationalist? } \\
\text { Very; A little; None }\end{array}$ & $\begin{array}{l}\text { Very: } 2 \\
\text { A little: } 1 \\
\text { None: } 0\end{array}$ \\
\hline \multicolumn{3}{|c|}{$\begin{array}{l}\text { The respondents were given the following instruction for questions 16-42: "Now I am going } \\
\text { to read you a series of sentences. Can you indicate your opinions on these questions as "I } \\
\text { agree," "I somewhat agree," and "I disagree"? }\end{array}$} \\
\hline $\begin{array}{l}\text { Position on primary } \\
\text { and middle school } \\
\text { children wearing } \\
\text { headscarves }\end{array}$ & $\begin{array}{l}\text { Q18. Female students attending } \\
\text { primary and middle school can } \\
\text { cover their heads during class. }\end{array}$ & $\begin{array}{l}\text { Agree: } 2 \\
\text { Somewhat agree: } 1 \\
\text { Disagree: } 0\end{array}$ \\
\hline
\end{tabular}




\begin{tabular}{|c|c|c|}
\hline $\begin{array}{l}\text { Position on Kurdish } \\
\text { language rights }\end{array}$ & $\begin{array}{l}\text { Q20. The education rights of the } \\
\text { Kurds in their own language should } \\
\text { be accepted. }\end{array}$ & $\begin{array}{l}\text { Agree: } 2 \\
\text { Somewhat agree: } 1 \\
\text { Disagree: } 0\end{array}$ \\
\hline $\begin{array}{l}\text { Belief in the } \\
\text { existence of } \\
\text { Ergenekon }\end{array}$ & $\begin{array}{l}\text { Q23. I believe that the Ergenekon } \\
\text { terrorist organization exists. }\end{array}$ & $\begin{array}{l}\text { Agree: } 2 \\
\text { Somewhat agree: } 1 \\
\text { Disagree: } 0\end{array}$ \\
\hline Trust in the police & Q27. I trust police officers. & $\begin{array}{l}\text { Agree: } 2 \\
\text { Somewhat agree: } 1 \\
\text { Disagree: } 0\end{array}$ \\
\hline Kurdish ethnicity & $\begin{array}{l}\text { Q48. All of us are Turkish citizens, } \\
\text { but we can be from different ethnic } \\
\text { roots. How would you feel or } \\
\text { identify yourself in terms of ethnic } \\
\text { roots? }\end{array}$ & $\begin{array}{l}\text { Kurd: } 1 \\
\text { Others: } 0\end{array}$ \\
\hline Income & $\begin{array}{l}\text { Q50. This is very important for our } \\
\text { survey, what is the monthly total } \\
\text { income of the people who live at } \\
\text { your home? Including everybody's } \\
\text { every type of earning, how many } \\
\text { liras enter your home on average } \\
\text { each month? }\end{array}$ & $\begin{array}{l}\text { in } 1000 \text { TL } \\
\text { (There were } 13 \text { respondents } \\
\text { who declared that their } \\
\text { household income was zero } \\
\text { Turkish liras and one } \\
\text { respondent who declared four } \\
\text { liras. The rest of the } \\
\text { respondents stated various } \\
\text { numbers ranging from } 100 \text { to } \\
15,000 \text { liras.) }\end{array}$ \\
\hline Religiosity & $\begin{array}{l}\text { Q52. Do you perform prayer } \\
\text { regularly, in other words every day, } \\
\text { five times a day? } \\
\text { Yes; No }\end{array}$ & $\begin{array}{l}\text { Yes: } 1 \\
\text { No: } 0\end{array}$ \\
\hline Place of residence & $\begin{array}{l}\text { Where the interview was conducted } \\
\text { Village; Town; Metropolis }\end{array}$ & $\begin{array}{l}\text { Metropolitan region: } 2 \\
\text { Town: } 1 \\
\text { Village: } 0\end{array}$ \\
\hline
\end{tabular}

